\title{
Could nanoparticle corona characterization help for biological consequence prediction?
}

\author{
Emilie Brun and Cécile Sicard - Roselli*
}

\author{
* Correspondence: \\ cecile.sicard@u-psud.fr \\ Laboratoire de Chimie Physique, \\ CNRS UMR8000, Université \\ Paris-Sud, 91405 Orsay, Cedex, \\ France
}

\begin{abstract}
As soon as they enter a biological medium (cell culture medium for in vitro, blood or plasma for in vivo studies), nanoparticles, in most cases, see their surface covered by biomolecules, especially proteins. What the cells see is thus not the ideal nanoparticle concocted by chemists, meaning the biomolecular corona could have great biological and physiological repercussions, sometimes masking the expected effects of purposely grafted molecules. In this review, we will mainly focus on gold nanoparticles. In the first part, we will discuss the fate of these particles once in a biological medium, especially in terms of size, and the protein composition of the corona. We will highlight the parameters influencing the quantity and the identity of the adsorbed proteins. In a second part, we will resume the main findings about the influence of a biomolecular corona on cellular uptake, toxicity, biodistribution and targeting ability. To be noticed is the need for standardized experiments and very precise reports of the protocols and methods used in the experimental sections to extract informative data. Given the biological consequences of this corona, we suggest that it should be taken into account in theoretical studies dealing with nanomaterials to better represent the biological environment.
\end{abstract}

Keywords: Gold nanoparticles; Culture medium; Protein corona; Protein identification; Cellular interaction; Hydrodynamic size; Nanoparticle uptake; Nanoparticle toxicity

\section{Background}

Since the beginning of the twentieth century [1], manufactured gold nanoparticles (GNP) have been constantly developed for biomedical applications, be it for diagnosis or therapy [2-5]. The enthusiasm aroused by their unique properties, among which spectroscopic and catalytic, and the possible progress they could generate, lead some to talk about a new "Golden Age" [4]. With years, the design of nanoparticles (NP) is complexifying, allowing multiple functionalities on the same object [6-8]. Such sophistication is not achievable with small organic molecules or metallic salts, which accounts for the impetus to consider NP as theragnostic platforms. However, once in a biological environment, NP are submitted to new interactions and constraints that could affect their performance (enzymatic digestion, mechanical stress due to rapid blood flow, corrosion, ligand exchange...). In particular, NP are expected to interact with biomolecules, such as proteins, lipids, nucleic acids and even metabolites, in large extent because of their large surface-to-mass ratio. In fact, the awareness that the synthetic identity of NP could greatly differ from their biological identity is now spreading.

\section{空

(c) 2014 Brun and Sicard-Roselli; licensee Springer. This is an Open Access article distributed under the terms of the Creative Commons Attribution License (http://creativecommons.org/licenses/by/4.0), which permits unrestricted use, distribution, and reproduction in any medium, provided the original work is properly credited. 
Because of proteins omnipresence in biological fluids and the increased number of highly sensitive analytical techniques, there has been a growing number of papers dealing with the formation of a protein corona at the surface of NP [9-12]. Usually, one distinguishes two components in this dynamic process: the soft and the hard coronas. Soft and hard coronas can be defined by their relative affinity for NP surface and exchange times. Hard corona is made by a protein fraction strongly bound to the surface while soft corona is formed by loosely-bound proteins, maybe via protein-protein interaction [10]. The protein corona can thus be multi-layered. NP surface may then get modified and the corona may substantially influence the biological response.

In this review, we will focus mainly on gold nanoparticles (GNP). In a first part, corona characterization will be summarized. We will attempt to draw the main findings regarding what happens to GNP in a biological fluid in terms of size, charge, aggregation state and corona composition. In a second part, we will wonder how this biomolecular corona influences cellular uptake, toxicity, biodistribution and targeting ability.

\section{Review}

\section{GNP size is expanded by biomolecular corona}

In the attempt to determine metallic NP size, a wide variety of techniques are now available allowing fine characterization [13]. The most commonly encountered are transmission electron microscopy (TEM), absorption UV-Visible spectroscopy to probe plasmon resonance (PR) and dynamic light scattering (DLS). Differential centrifugal sedimentation (DCS) and, more recently, nanoparticle tracking analysis (NTA) were also developed to determine NP hydrodynamic parameters. Figure 1 presents some of the results one can obtain from such techniques. TEM can be considered as the most direct method to visualize NP and determine metallic core shape and dimensions. For reliable results, it necessitates a manual measurement of objects, considered sufficient for a few hundreds of particles [14,15] (Figure 1, left upper part). In addition to core, coloration treatments, with uranyl acetate for example [16], could allow coating visualization and thickness estimation (Figure 1, left bottom part). Specific to metallic $\mathrm{NP}$, plasmon resonance (PR), which is the collective oscillation of electrons at the metallic surface, also gives access to size information $[17,18]$. GNP plasmon resonance is located in the visible region at $c a .530 \mathrm{~nm}$ and for citrate-capped GNP, the wavelength of PR varies linearly with diameters from 10 to $70 \mathrm{~nm}$ and with a steeper dependence beyond [19-22] (Figure 1, right upper part). This easy-to-use spectroscopy then appears as very powerful and therefore essential for NP size control. Resonance plasmon wavelength is also sensitive to ligand grafting or NP aggregation. Nevertheless, no precise characteristic about the coating can be extracted from such a parameter. On the contrary, DLS $[23,24]$ and NTA $[25,26]$ rely on brownian movements of nanoparticles. Furthermore, DCS [27-29] offers measurements of NP size including both their core and shell according to sedimentation through a density gradient, that allows computing of diameter details linked to the ligand shell in the case of monolayer protected clusters and other particles. Hydrodynamic diameter is defined as the NP diameter implemented with a diffuse layer made of solvent molecules and ions present in solution and with grafted molecules when functionalization was performed (Figure 1, central part). One advantage of DLS is that, contrary to TEM, it allows the analysis of a high number 


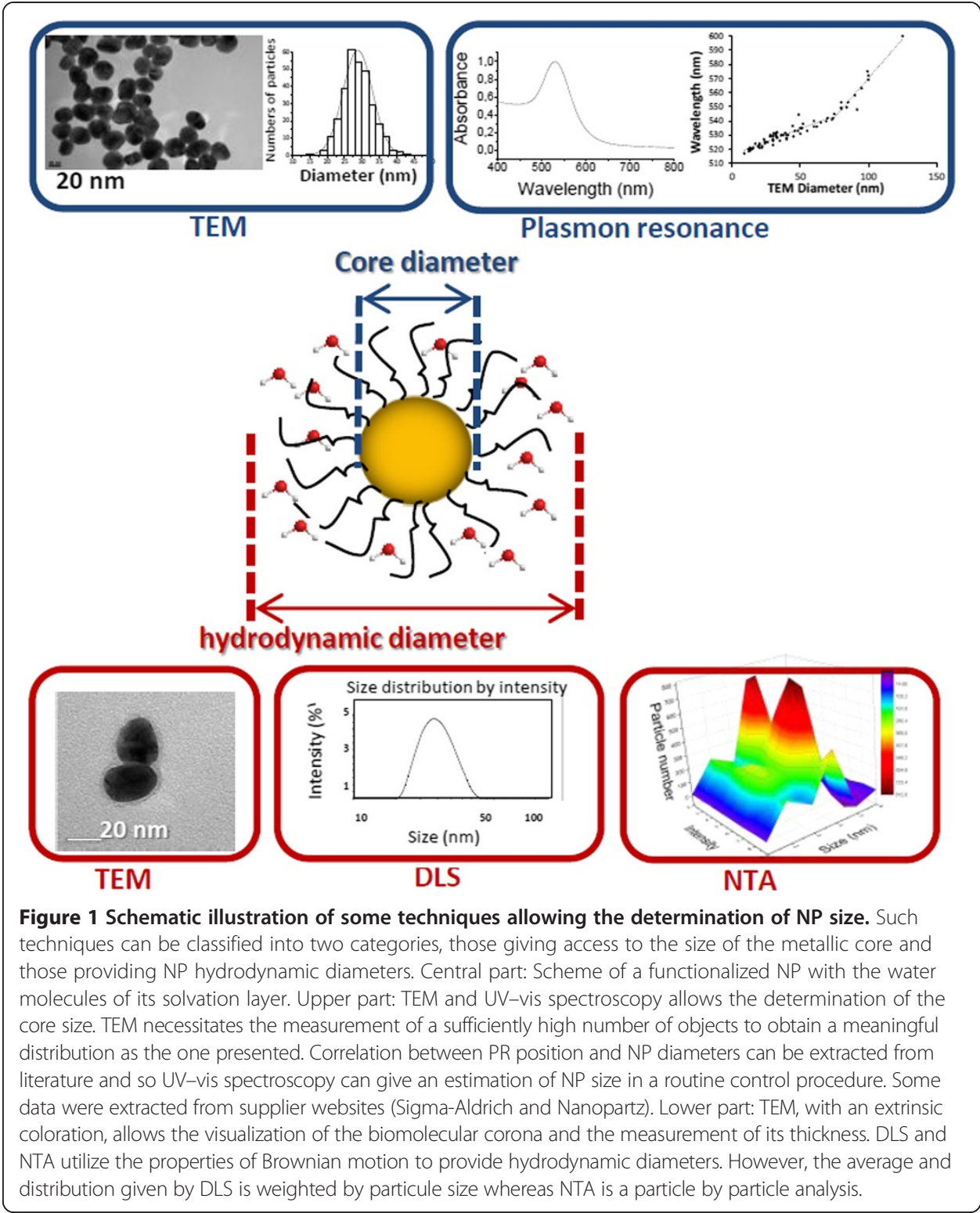

of objects as a few microliters of solution can be scanned by the laser. This statistic analysis leads to an average and accurate size distribution if experimental conditions are carefully optimized [24,30,31]. DLS is more documented for protein corona analysis, especially for GNP, though care should be taken about large particle contribution because the scattered light intensity varies as $D^{6}(D=N P$ diameter $)$, which is not the case for NTA which analyses each particle individually (Figure 1, bottom part). As DLS can provide results in intensity, volume and number, attention should be paid as the raw data are expressed in intensity and do not represent the relative proportions of small and large particles in the sample. To be noticed, some claims that only the hard corona is probed by DLS measurements [32]. As for DCS, one of its advantages is the sensitivity of this method to small surfaces changes [27]. Combination of these techniques then leads to a precise corona thickness depiction. 
Table 1 lists GNP characterization in different media. According to these studies, when GNP are dispersed in biological fluids, DLS shows an increase of their hydrodynamic size. As mentioned in several references of Table 1, based on DLS only, agglomeration cannot be excluded. To get information on this point, several authors performed UV-visible spectroscopy and plasmon resonance generally confirms that, in the presence of fetal calf serum (FCS), size increases are the result of protein adsorption: PR shifts due to a change of refractive index. DCS can also give valuable information on aggregation patterns, however it is less used until now. On the contrary, physiological conditions in the absence of FCS seem to induce predominantly agglomeration [33]. Corona formation is expected to depend on several parameters such as size, charge and coating of GNP. For non-coated GNP, according to Maiorano [34], citrate-GNP size determined by DLS in DMEM supplemented with FCS is about $200 \mathrm{~nm}$ whatever their original size is (Table 1). This is not in agreement with Wang who showed that $20 \mathrm{~nm}$ citrate- NP diameter increases from 20 to $83 \mathrm{~nm}$ in DMEM with FCS [35] and with Casals who reported a modification from 24 to $45 \mathrm{~nm}$ [36]. For

Table 1 Hydrodynamic diameters of gold nanoparticles : evolution in several biological media

\begin{tabular}{|c|c|c|c|c|c|c|c|c|c|}
\hline \multirow[t]{2}{*}{$\begin{array}{l}\text { NP } \\
\text { coating }\end{array}$} & \multirow{2}{*}{$\begin{array}{l}\text { Zeta } \\
\text { potential } \\
(\mathrm{mV})\end{array}$} & \multicolumn{2}{|c|}{ Diameter (nm) } & \multirow{2}{*}{$\begin{array}{l}\text { DLS } \\
\text { temperature } \\
\text { measurement } \\
\left({ }^{\circ} \mathrm{C}\right)\end{array}$} & \multicolumn{3}{|c|}{$\begin{array}{l}\text { Hydrodynamic diameter } \\
\text { in biological media (nm) }\end{array}$} & \multirow{2}{*}{$\begin{array}{l}\text { NP } \\
\text { incubation } \\
\text { time in } \\
\text { medium }\end{array}$} & \multirow{2}{*}{ Ref. } \\
\hline & & $\begin{array}{l}\text { Core } \\
\text { (MET) }\end{array}$ & $\begin{array}{l}\text { Hydrodynamic } \\
\text { (DLS) }\end{array}$ & & $\begin{array}{l}\text { RPMI } \\
+ \text { FCS }\end{array}$ & $\begin{array}{l}\text { DMEM } \\
+ \text { FCS }\end{array}$ & Plasma & & \\
\hline \multirow[t]{11}{*}{ citrate } & & 15 & & & 40 & 200 & & & [34] \\
\hline & & 40 & & & 70 & 200 & & & [34] \\
\hline & & 80 & & & 150 & 200 & & & [34] \\
\hline & $-21^{*}$ & 20 & & & & 83 & & & [35] \\
\hline & -38 & 30 & 33 & 25 & & & 76 & $30 \mathrm{~min}$ & [40] \\
\hline & -34 & 50 & 55 & 25 & & & 100 & $30 \mathrm{~min}$ & [40] \\
\hline & -33 & 4 & 5.3 & & & 6.1 & & $48 \mathrm{~h}$ & [36] \\
\hline & -44 & 10 & 10.1 & & & 16.4 & & $48 \mathrm{~h}$ & [36] \\
\hline & -42 & 13 & 13.1 & & & 22.3 & & $48 \mathrm{~h}$ & [36] \\
\hline & -43 & 24 & 24.2 & & & 44.7 & & $48 \mathrm{~h}$ & [36] \\
\hline & -45 & 40 & 40.6 & & & 59.6 & & $48 \mathrm{~h}$ & [36] \\
\hline $\mathrm{NH}_{3}^{+}$ & 64 & 10 & 12 & & & 40.7 & & $48 \mathrm{~h}$ & [36] \\
\hline \multirow[t]{5}{*}{$\mathrm{COO}^{-}$} & & 10 & 24 & & & 108 & & & [33] \\
\hline & & 25 & 41 & & & 95 & & & [33] \\
\hline & & 50 & 65 & & & 88 & & & [33] \\
\hline & & 100 & 97 & & & 110 & & & [33] \\
\hline & -56 & 10 & 12 & & & 11.8 & & $48 \mathrm{~h}$ & [36] \\
\hline \multirow[t]{3}{*}{ TPPBS } & -35 & 5 & 11 & 25 & & 63.2 & & & [32] \\
\hline & -32 & 15 & 19 & 25 & & 75.6 & & & [32] \\
\hline & -43 & 80 & 88.3 & 25 & & 122.3 & & & [32] \\
\hline peptide & $-18^{*}$ & 20 & & & & 45 & & & [35] \\
\hline
\end{tabular}

When available, characteristics of nanoparticles are indicated (zeta potential, core diameter, hydrodynamic diameter in water) as well as the media composition and the incubation time. As underlined in the text, most studies do not give details about their DLS measurement conditions. 
functionalized GNP, this dynamic process, mostly governed by electrostatic interaction, is influenced by the presence of a specific charge and/or coating. In DMEM with serum, $\mathrm{COOH}$-coated objects which exhibit additional negative charge from the carboxylate groups at physiological $\mathrm{pH}$ swell up to $c a .100 \mathrm{~nm}$ whatever their original size [33]. A similar tendency was evidenced by Casals et al. but with a lower final size [36]. NP-TTPPBS (bis-sulfonatetriphenylphosphine) in DMEM exhibit a large increase for small objects $(<20 \mathrm{~nm})$ and a weaker one for $88 \mathrm{~nm} \mathrm{NP}$ [32]. It seems anyhow that the smaller GNP, the higher diameter rise. Moreover, the type of medium induces a different behavior as shown by Maiorano comparing DMEM and RPMI for which final sizes and protein adsorption kinetics prove to be different [34].

These examples highlight the absence of any consensus concerning the extent of GNP size increase by the biomolecular corona. Indeed, it should be noticed that in Wang et al., DLS measurements were performed after centrifugation and resuspension of the sample in a buffer, preparation that could remove a high quantity of loosely bound proteins. DLS temperature measurements should also be considered as it can modify protein/NP association [37]. These particularities illustrate the fact that experimental conditions are decisive. Comparison of different assays can be hazardous when DLS measurements are not performed under identical conditions. Pitfalls could then arise from diversified NP time of incubation in the medium and with cells, temperature of DLS analysis, order of component mixing (serum/medium/NP), .... Then a fine reading and comparison of experimental conditions appear necessary to extract any tendency of NP behavior in physiological medium.

\section{Corona composition: proteins identification and quantification}

Functionalization appears here as a decisive parameter for the quantity and identity of proteins implicated in NP corona. As polyethyleneglycol (PEG) is the most frequently grafted polymer on NP to reduce opsonization, it has been most studied. First, it has been clearly demonstrated by Walkey et al. that for a constant GNP size, PEG grafting increase leads to a total protein adsorption decrease [38]. Indeed, weak PEG density was shown to reduce the thermodynamic barrier to protein adsorption. In the case of a constant ligand grafting, the size of the NP seems crucial as its lowering enhances total protein adsorption. This was also demonstrated in ref [32]. Dobrovolskaia also showed that increasing PEG molecular weight grafted on GNP diminishes the total amount of adsorbed proteins [39].

To identify proteins in the corona, two main approaches are commonly used: 1D and 2D SDS-PAGE and mass spectrometry. Nevertheless, here also sample preparation and conditioning can perturb the protein corona. As a consequence, mainly hard corona is analyzed showing anyhow more than nearly one hundred different proteins [40-42].

Electrophoresis, a routine technique, has allowed evidencing the quantity of total proteins and their mass repartition in most studies so far. To be noticed is also the development of micro-BCA or Bradford assay as a tool for relative protein quantification in samples but far fewer papers refer to this technique [43]. NP charge and hydrophobicity appear crucial for the identity of proteins bound to NP as electrostatic interactions are often responsible for the hard corona formation. Unsurprisingly, Casals et al. evidenced negatively-charged serum proteins adsorbed on positively-charged GNP [36]. Moreover, 
small NP seem to bind more specifically small proteins: 5-50 kDa proteins represent respectively $15 \%$ and $2 \%$ of total for GNP which diameters are $<10 \mathrm{~nm}$ and equal to $80 \mathrm{~nm}$ [32]. Coating density is also a key parameter: Walkey et al. identified 147 proteins at the surface of pegylated NP and correlated a high PEG density with a smaller range of protein size present [38]. More precisely, 50 to $80 \mathrm{kDa}$ proteins were more abundant on highly-grafted pegylated NP. In addition, Dobrovolskaia showed that NP pegylation doesn't change the type of plasma protein composition of the corona though it changes the total amount of proteins [39].

Protein identification has benefited from proteomic approaches and increased sensitivity of apparatus. First, it is to be noticed that the composition of the corona is not the reflect of the surrounding medium, which seems to be independent of the NP type $[34,42,44]$. By mass spectrometry, the major proteins identified in the corona of GNP in complete cell culture medium are albumin, immunoglobulin and fibrinogen or glycoproteins as can be expected from the presence of FCS $[33,34,36]$. In addition, complement factor C3 was shown to be predominant for ungrafted NP representing ca. $30 \%(\mathrm{w} / \mathrm{w})$ of total proteins or $5 \%$ for a high density PEG functionalization [32,38]. Dobrovolskaia also detected this complement protein on citrate-coated NP without any induction of activation. It is also important to notice the presence of fibrinogen but without any platelet activation [32,40]. A meaningful example of LC-MS/MS analysis performance is the study of Sisco et al., where distinction between bovine proteins from serum and proteins produced by the rat fibroblasts was achieved, pointing out a possible biological role of rat biglycan protein sequestration in the corona of NR [45]. Albanese et al. also profited by the analytical power of mass spectrometry to show that cell-secreted proteins progressively replace serum proteins in the protein corona around citrate-coated GNP in a time- and phenotype-dependent manner, underlying protein corona is a dynamic process [46].

Some studies carefully depicted corona composition with more than one hundred proteins identified. Nevertheless it is utopic to believe that complete corona analysis is accomplished. Given the huge number of different proteins in corona, only part of them is identified. It cannot be excluded that some proteins present at a minor level and so not cited in the literature could be responsible for the major biological consequences discussed below. Considering the variety of nanomaterials in nature, size, shape and coating as long as the different sources of proteins and cell lines, it is difficult to draw absolute conclusions. Still, we believe some trends to be trustworthy. We will uppermost examine studies with GNP but given the paucity of data, we will sometimes refer to other NP.

\section{The presence of the corona reduces non-specific cellular uptake}

A first question of interest is: does the biomolecular corona increase NP uptake by cells? At this point we must distinguish non-specific from specific uptake. Specific internalization is regulated by membrane receptors that are only activated by receptor-specific ligands to trigger internalization. Non-specific uptake is a random process without specific biomolecular control by the cell. We will discuss first the non-specific process.

When studying the impact of serum proteins on cellular uptake, it seems clear that the extent of NP internalization depends greatly on the presence of a corona. 
Comparing DMEM with and without 10\% FBS, Wang et al. observed a one order of magnitude higher uptake without serum for two different peptide-coated GNP [35]. For oligonucleotide-functionalized GNP, Patel et al. reported a 150\% increase in uptake in serum-free medium [47]. Similarly, the uptake of FePt NP or quantum dots (QDs) by HeLa cells were greatly reduced by the formation of a corona compared to the bare NP [48,49]. This trend was also reported for A549 cells with silica NP [50] or with carboxylated polystyrene NP, with the highest uptake occurring in serum-free MEM [51], for human macrophages with a 4-fold uptake of polystyrene NP in HBSS than in 10\% human serum RPMI [52], and for mouse macrophages [53]. Once covered with similar biomolecular corona, it seems that same-shaped NP behave the same whatever their core composition. More precisely, the total amount of proteins in the corona seems to impact the extent of uptake. For example, GNP of 15, 40 and $80 \mathrm{~nm}$ showed all a different behavior in DMEM and RPMI media supplemented with $10 \%$ FBS, with a more abundant corona formed in DMEM. Even though HeLa cells exhibit the same growth rate in the two media, a lower uptake of NP was reported in DMEM [34]. More intriguing, serum heat inactivation also seems to influence NP uptake, even for A549 cells that are known to be insensitive to the complement: a correlation was found between more proteins in the hard corona in the case of heatinactivated serum and a lower uptake [54]. The reason evoked is the reduction of particles cell membrane adhesion when a biomolecular corona is formed [51,55].

Interestingly, a few studies reported that the biomolecular corona could promote specific uptake: for a couple (NP, cell line) showing the folate-receptor involvement, selective uptake was annihilated without serum [56]. In a differentiated macrophage-like cell line (dTHP1), surexpressing the class A scavenger receptor (SR-A) in charge of the recognition of modified proteins and lipoproteins for their subsequent clearance, Yan et al. did not observe any change in effective association and internalization with the presence of serum [55]. But they suggested that the SR-A mediated phagocytosis is only active in the presence of the corona through the recognition of unfolded BSA at the surface of the NP. Prapainop et al. also addressed the question of a relationship between misfolded proteins in the corona and cellular uptake by macrophages: they grafted an inflammatory metabolite (cholesterol 5,6-secosterol atheronal B) known to affect protein folding on QDs, and reported a measurable QD uptake for concentration of $10 \mathrm{nM}$ whereas atheronal-free QDs were not taken up by cells even at $100 \mathrm{nM}$ [57]. As for Caracciolo et al., they suggested that NP, through the formation of a protein corona, could target specific cells if among the main coating proteins resides one, still functional, which receptor is overexpressed in diseased cells [58].

So non-specific uptake seems to be decreased in the presence of a corona whereas specific uptake seems to be promoted, sometimes at least, by the protein corona, because a misfolding of corona proteins trigger NP uptake by specific cells that otherwise would not have done so or because there is a protein in the corona able to target a specific receptor expressed in the cell line used. All these results highlight how important each cell line specificity is. Beyond the evident biological relevance of these new findings, they could also allow the reconsideration of a whole part of literature as regards inconsistencies in NP uptake studies as incubation conditions, and especially serum presence, seem to play a major role.

\section{The presence of the corona generally reduces NP toxicity}

As a consequence of a lower uptake, the presence of the corona induces a lower toxicity of nanomaterials. This was, for example, emphasized by a complete set of toxicity 
assays in Maiorano's comparison of GNP diluted in DMEM and RPMI [34]. Several observables were quantified: mitochondrial activity through WST-8 assay, membrane integrity with LDH release measurement, apoptosis by flow cytometry and DNA fragmentation with Tunel test. Possible interferences between GNP and the different assays were verified, allowing to state with certainty that the smaller corona GNP induce the higher uptake and the higher toxicity. This has also been reported for carbon nanotubes [59], graphene oxide nanosheets [60] or biopolymeric NP in several cell lines [53]. In the case of well-known toxic nanomaterials such as CTAB-coated gold nanorods (NR) or positively-charged polystyrene NP, the biomolecular corona also plays a protective role as regards membrane damage [61,62]. With FBS-coated CTAB NR, within a $24 \mathrm{~h}$ time frame, no morphological impairment of the membrane such as blebs or loss of microvilli was observed, suggesting the corona prevents the amphiphilic $\mathrm{CTAB}$ from interacting with the phospholipid bilayer. Interestingly, it has been shown recently that the corona remains bound during internalization and trafficking inside the cell [61-63]. This means that the protective effect of the corona could last as long as it is intact and effectively, a delayed toxicity was observed in the previous cited studies, corresponding to the degradation of the corona inside the lysosomes and the reexposition of the toxic surface [61-63]. Nevertheless, to the best of our knowledge, such study does not exist yet for GNP.

However, toxicity could be triggered, related to endogenous proteins modifications at the NP surface. This could imply a modulation of biological activity, as observed for cathepsins B and L in the presence of GNP [64] possibly leading to an impairment of the cell machinery, a recognition of immunoglobulins or unfolded protein leading to macrophage activation [55,65] and inflammation [66].

It has also been suggested to take advantage of the protein corona to load small molecular therapeutics such as DNA or doxorubicin $[67,68]$ to induce a toxicity to cancerous cells. Corona seems to act as sponge with a higher payload capacity than what is observed with covalent conjugation strategies. Passive release can be tuned by varying the corona composition and a triggered drug release can be achieved by laser excitation at the longitudinal PR of the gold NR. This pioneering work underlines that, as corona formation is unavoidable, a strategy is needed to exploit it.

\section{The presence of the corona influences biodistribution}

If the influence of NP PEGylation on biodistribution is known for years [69-72], the thorough characterization and consequences of a biomolecular corona formed in vivo has not been investigated yet. However, of interest are several studies dealing with a pre-coating of the NP with proteins, namely with serum albumin and apolipoprotein E $[53,73,74]$. Whatever the nature of the NP core, polymeric or metallic, it seems that such a pre-coating increases the blood circulation time and reduces the clearance speed. For example, a 6-fold increase of half-time was reported by Peng for BSA-precoated NP compared to "bare" NP [53]. Based upon in vitro experiments, the authors proposed as an explanation a weakened opsonization and a reduced phagocytosis. In all these studies, liver stays the main organ of NP accumulation (more than $90 \%$ of the injected dose after $19 \mathrm{~h}$ [74]). Still, the protein used for pre-coating seems to nuance the amounts of NP in other organs, albumin targeting lungs preferentially, and brain to 
a lesser extent, compared to apo-E [74]. One could take advantage of this improved retention when pre-coating NP with albumin in cancer therapy as specific factors account for the accumulation of this protein in solid tumors: a decreased level of HSA in cancer patients, inducing a need for albumin digestion to cover the need in amino acids for tumor growth and the presence of two albumin receptors, gp60 in tumor endothelium and SPARC in tumor interstitium [75].

\section{The presence of the corona impacts targeting ability}

When it comes to therapeutic applications, one main advantage of NP is the multifunctional platform they can become: to address them to diseased cells, functionalization of their surfaces with antibodies, aptamers or other biomolecules is usually involved. Using a click chemistry reaction between azide-functionalized surfaces and bicyclononynesilica NP (BCN-NP) as a model of targeting, Mirshafiee and coll quantified the targeting efficiencies of such NP in the presence of 10 or $100 \%$ FBS : they were lowered by 94 and $99 \%$ respectively compared to bare BCN-NP [76]. Such a loss of recognition between the ligand and its target was also depicted in cellular experiments. Constructing gold nanoconjugates with a KDEL-labelled peptide, meant to activate a specific transport pathway, and with a random sequence peptide as a control, Wang et al. concluded that, in the presence of serum, non-specific mechanisms of uptake were more robust [35]. Similar results were obtained in the study of transferrin (Tf)-functionalized silica NP [77]: with increasing serum concentration, the targeting capacity of Tf-NP was lost, even when a secondary PEG layer was added to control unspecific protein binding. These observations emphasize that the grafting of a functional ligand is not enough to guarantee the recognition by the corresponding receptor. The biomolecular corona seems to act as a "screen", preventing NP to discriminate the "right" cells. More recently, Dai et al. showed that choosing the correct length of PEG chains could allow to re-establish a selective targeting in the presence of serum [78], suggesting strategies to overcome this difficulty.

\section{Conclusions}

In this review, we wondered what happens to GNP once in cell culture medium. In the presence of serum, what the cell sees is a larger object, the smaller particles being more affected. NP charge can also be modified. Quantity and identity of proteins in the corona are affected by NP size and charge but also by functionalization. In any case, the composition of the corona is not the exact reflect of the composition of the biological fluid: there is a selection process. Extracting general conclusions was awkward as examining this limited body of literature evidences the high importance of carrying standardized experiments, knowing techniques limitations and writing well-documented experimental sections to enable cross-comparisons between studies.

We also highlighted that the interest raised by the biomolecular corona would have been limited without the analytical developments of the recent years. Powerful and sensitive techniques are now available to describe and follow protein corona composition in vitro. A new challenge is now to follow it in vivo. As culture medium presents a protein composition different from biological fluids, data on protein coronas in both cases could perhaps explain why extrapolation from vitro to vivo experiments is so difficult. 
As for biological consequences, biomolecular corona has pros and cons. On the one hand, it could reduce toxicity, promote in some cases specific uptake and nuance biodistribution, on the other hand it could lead to inflammation processes after activation of macrophages if misfolded proteins are recognized and screen targeted molecules grafted on NP surface. Nowadays, one cannot predict the composition of the corona and its biological consequences: further studies are needed to know how to exploit the benefits of such corona in vivo. Moreover, now that biomolecular corona prevalence is well-established, it has to diffuse among a larger scientific community. In particular, it should be included in theoretical studies and simulations, for example dealing with heat transfer induced by NP for hyperthermia. Its consequences in imaging should also be investigated as biomolecular corona might affect fluorescence properties of NP or fluorescent molecules grafted at their surface.

\begin{abstract}
Abbreviations
Apo-E: Apolipoprotein E; BCA: Bicinchoninic acid; BCN-NP: Bicyclononyne-silica nanoparticle; BSA: Bovine serum albumin; CTAB: Cetyl trimethylammonium bromide; DCS: Differential centrifugal sedimentation; DLS: Dynamic light scattering; DMEM: Dulbecco's modified eagle medium; FBS: Fetal bovine serum; FCS: Fetal calf serum; GNP: Gold nanoparticle; HBSS: Hank's balanced salt solution; HSA: Human serum albumin; MEM: Modified eagle medium; NP: Nanoparticle; NR: Nanorod; NTA: Nanoparticle tracking analysis; PEG: Polyethyleneglycol; PR: Plasmon resonance; QD: Quantum dot; RPMI: Roswell Park Memorial Institute medium; SDS-PAGE: Sodium dodecyl sulfate polyacrylamide gel electrophoresis; SR-A: Class A scavenger receptor; TEM: Transmission electronic microscopy; Tf: Transferrin.
\end{abstract}

Competing interests

The authors declare that they have no competing interests.

Authors' contributions

EB and CSR equally contributed to the manuscript. All authors read and approved the final manuscript.

\begin{abstract}
Author's information
EB obtained her Ph. D in Université Paris Sud (France) in 2009. She is an associate professor in the Laboratoire de Chimie Physique (Université Paris Sud UMR CNRS 8000). Her research deals with nanoparticles interaction with cells and radiobiology.

CSR obtained her Ph. D in Université Paris Sud (France) in 1995. She has an associate professor position in the Laboratoire de Chimie Physique (Université Paris Sud UMR CNRS 8000). Her area of research includes radiobiology, analytical chemistry and nanosciences.
\end{abstract}

\title{
Acknowledgements
}

This work has benefited from the facilities and expertise of the Imagif Cell Biology Unit of the Gif campus (https://www.imagif.cnrs.fr) which is supported by the Conseil Général de l'Essonne.

Received: 20 May 2014 Accepted: 11 September 2014

Published online: 01 October 2014

\section{References}

1. Lange CFA (1913) Über die Ausflockung kolloidalen Goldes durch Zerebrospinalflüssigket bei luetischen Affektionen des Zentralnervensystems. Zeitschrift für Chemotherapie und verwandte Gebiete 1:44-78

2. Ahmad MZ, Akhter S, Rahman Z, Akhter S, Anwar M, Mallik N, Ahmad FJ (2013) Nanometric gold in cancer nanotechnology: current status and future prospect. J Pharm Pharmacol 65:634-651

3. Boisselier E, Astruc D (2009) Gold nanoparticles in nanomedicine: preparations, imaging, diagnostics, therapies and toxicity. Chem Soc Rev 38:1759-1782

4. Dreaden EC, Alkilany AM, Huang X, Murphy CJ, El-Sayed MA (2012) The golden age: gold nanoparticles for biomedicine. Chem Soc Rev 41:2740-2779

5. Kumar D, Saini N, Jain N, Sareen R, Pandit V (2013) Gold nanoparticles: an era in bionanotechnology. Expert Opin Drug Deliv 10:397-409

6. Cobley CM, Chen J, Cho EC, Wang LV, Xia Y (2011) Gold nanostructures: a class of multifunctional materials for biomedical applications. Chem Soc Rev 40:44-56

7. Jiao PF, Zhou HY, Chen LX, Yan B (2011) Cancer-targeting multifunctionalized gold nanoparticles in imaging and therapy. Curr Med Chem 18:2086-2102

8. Mieszawska AJ, Mulder WJ, Fayad ZA, Cormode DP (2013) Multifunctional gold nanoparticles for diagnosis and therapy of disease. Mol Pharm 10:831-847

9. Lynch I, Dawson KA (2008) Protein-nanoparticle interactions. Nano Today 3:40-47

10. Rahman M, Laurent S, Tawil N, Yahia L, Mahmoudi M (2013) Protein-Nanoparticle Interactions. Springer, Berlin Heidelberg

11. Saptarshi SR, Duschl A, Lopata AL (2013) Interaction of nanoparticles with proteins: relation to bio-reactivity of the nanoparticle. J Nanobiotechnol 11:26 
12. Walkey CD, Chan WCW (2012) Understanding and controlling the interaction of nanomaterials with proteins in a physiological environment. Chem Soc Rev 41:2780-2799

13. Lin PC, Lin S, Wang PC, Sridhar R (2014) Techniques for physicochemical characterization of nanomaterials. Biotechnol Adv 32:711-726

14. Herrera J, Sakulchaicharoen N (2009) Microscopic And Spectroscopic Characterization Of Nanoparticles. In: Pathak Y, Thassu D (eds) Nanoparticulate Drug Delivery Systems. Informa Healthcare, New York, pp 237-249

15. Klang V, Valenta C, Matsko NB (2013) Electron microscopy of pharmaceutical systems. Micron 44:45-74

16. McDonald KL (2014) Out with the old and in with the new: rapid specimen preparation procedures for electron microscopy of sectioned biological material. Protoplasma 251:429-448

17. Pluchery O (2012) Optical Properties of Gold Nanoparticles. In: Louis C, Pluchery O (eds) Gold Nanoparticles for Physics, Chemistry and Biology. London: Imperial College Press; pp 43-73

18. Haiss W, Thanh NTK, Aveyard J, Fernig DG (2007) Determination of size and concentration of gold nanoparticles from UV-vis spectra. Anal Chem 79:4215-4221

19. Brun E, Sanche L, Sicard-Roselli C (2009) Parameters governing gold nanoparticle X-ray radiosensitization of DNA in solution. Colloids Surf B: Biointerfaces 72:128-134

20. He YQ, Liu SP, Kong L, Liu ZF (2005) A study on the sizes and concentrations of gold nanoparticles by spectra of absorption, resonance Rayleigh scattering and resonance non-linear scattering. Spectrochim Acta, Pt A: Mol Spectrosc 61:2861-2866

21. Link S, El-Sayed MA (1999) Size and temperature dependence of the plasmon absorption of colloidal gold nanoparticles. J Phys Chem B 103:4212-4217

22. Nath N, Chilkoti A (2004) Label-free biosensing by surface plasmon resonance of nanoparticles on glass: optimization of nanoparticle size. Anal Chem 76:5370-5378

23. Brar SK, Verma M (2011) Measurement of nanoparticles by light-scattering techniques. Trac-Trend Anal Chem 30:4-17

24. Roebben G, Ramirez-Garcia S, Hackley VA, Roesslein M, Klaessig F, Kestens V, Lynch I, Garner CM, Rawle A, Elder A Colvin VL, Kreyling W, Krug HF, Lewicka ZA, McNeil S, Nel A, Patri A, Wick P, Wiesner M, Xia T, Oberdorster G, Dawson KA (2011) Interlaboratory comparison of size and surface charge measurements on nanoparticles prior to biological impact assessment. J Nanopart Res 13:2675-2687

25. Filipe V, Hawe A, Jiskoot W (2010) Critical Evaluation of Nanoparticle Tracking Analysis (NTA) by nanosight for the measurement of nanoparticles and protein aggregates. Pharm Res 27:796-810

26. Hole P, Sillence K, Hannell C, Maguire CM, Roesslein M, Suarez G, Capracotta S, Magdolenova Z, Horev-Azaria L, Dybowska A, Cooke L, Haase A, Contal S, Mano S, Vennemann A, Sauvain JJ, Staunton KC, Anguissola S, Luch A, Dusinska M, Korenstein R, Gutleb AC, Wiemann M, Prina-Mello A, Riediker M, Wick P (2013) Interlaboratory comparison of size measurements on nanoparticles using nanoparticle tracking analysis (NTA). J Nanopart Res 15(12) doi 10.1007/S11051-013-2101-8

27. Krpetic Z, Davidson AM, Volk M, Levy R, Brust M, Cooper DL (2013) High-resolution sizing of monolayer-protected gold clusters by differential centrifugal sedimentation. ACS Nano 7:8881-8890

28. Monopoli MP, Walczyk D, Campbell A, Elia G, Lynch I, Bombelli FB, Dawson KA (2011) Physical-chemical aspects of protein corona: relevance to in Vitro and in Vivo biological impacts of nanoparticles. J Am Chem Soc 133:2525-2534

29. Jedlovszky-Hajdu A, Bombelli FB, Monopoli MP, Tombacz E, Dawson KA (2012) Surface coatings shape the protein corona of SPIONs with relevance to their application in vivo. Langmuir 28:14983-14991

30. Hinterwirth H, Wiedmer SK, Moilanen M, Lehner A, Allmaier G, Waitz T, Lindner W, Lammerhofer M (2013) Comparative method evaluation for size and size-distribution analysis of gold nanoparticles. J Sep Sci 36:2952-2961

31. Khlebtsov BN, Khlebtsov NG (2011) On the measurement of gold nanoparticle sizes by the dynamic light scattering method. Colloid J 73:118-127

32. Schaffler M, Semmler-Behnke M, Sarioglu H, Takenaka S, Wenk A, Schleh C, Hauck SM, Johnston BD, Kreyling WG (2013) Serum protein identification and quantification of the corona of 5, 15 and $80 \mathrm{~nm}$ gold nanoparticles. Nanotechnology 24:265103

33. Sabuncu AC, Grubbs J, Qian S, Abdel-Fattah TM, Stacey MW, Beskok A (2012) Probing nanoparticle interactions in cell culture media. Colloids Surf B: Biointerfaces 95:96-102

34. Maiorano G, Sabella S, Sorce B, Brunetti V, Malvindi MA, Cingolani R, Pompa PP (2010) Effects of cell culture media on the dynamic formation of protein-nanoparticle complexes and influence on the cellular response. ACS Nano 4:7481-7491

35. Wang G, Papasani MR, Cheguru P, Hrdlicka PJ, Hill RA (2012) Gold-peptide nanoconjugate cellular uptake is modulated by serum proteins. Nanomed Nanotechnol Biol Med 8:822-832

36. Casals E, Pfaller T, Duschl A, Oostingh GJ, Puntes V (2010) Time evolution of the nanoparticle protein corona. ACS Nano 4:3623-3632

37. Mahmoudi M, Abdelmonem AM, Behzadi S, Clement JH, Dutz S, Ejtehadi MR, Hartmann R, Kantner K, Linne U, Maffre P, Metzler S, Moghadam MK, Pfeiffer C, Rezaei M, Ruiz-Lozano P, Serpooshan V, Shokrgozar MA, Nienhaus GU, Parak WJ (2013) Temperature: the "ignored" factor at the nanobio interface. ACS Nano 7:6555-6562

38. Walkey CD, Olsen JB, Guo H, Emili A, Chan WC (2012) Nanoparticle size and surface chemistry determine serum protein adsorption and macrophage uptake. J Am Chem Soc 134:2139-2147

39. Dobrovolskaia MA, Neun BW, Man S, Ye X, Hansen M, Patri AK, Crist RM, McNeil SE (2014) Protein corona composition does not accurately predict hematocompatibility of colloidal gold nanoparticles. Nanomedicine, doi:10.1016/j.nano.2014.01.009

40. Dobrovolskaia MA, Patri AK, Zheng J, Clogston JD, Ayub N, Aggarwal P, Neun BW, Hall JB, McNeil SE (2009) Interaction of colloidal gold nanoparticles with human blood: effects on particle size and analysis of plasma protein binding profiles. Nanomedicine 5:106-117

41. Walkey CD, Olsen JB, Guo HB, Emili A, Chan W (2012) Nanoparticle size and PEG grafting density control protein adsorption and cellular interactions in a physiological environment. Abstr Pap Am Chem S 243, WOS:000324475104157.

42. Walkey CD, Olsen JB, Song F, Liu R, Guo H, Olsen DW, Cohen Y, Emili A, Chan WC (2014) Protein corona fingerprinting predicts the cellular interaction of gold and silver nanoparticles. ACS Nano 8:2439-2455 
43. Pozzi D, Colapicchioni V, Caracciolo G, Piovesana S, Capriotti AL, Palchetti S, De Grossi S, Riccioli A, Amenitsch H, Lagana A (2014) Effect of polyethyleneglycol (PEG) chain length on the bio-nano-interactions between PEGylated lipid nanoparticles and biological fluids: from nanostructure to uptake in cancer cells. Nanoscale 6:2782-2792

44. Tenzer S, Docter D, Rosfa S, Wlodarski A, Kuharev J, Rekik A, Knauer SK, Bantz C, Nawroth T, Bier C, Sirirattanapan J, Mann W, Treuel L, Zellner R, Maskos M, Schild H, Stauber RH (2011) Nanoparticle size is a critical physicochemical determinant of the human blood plasma corona: a comprehensive quantitative proteomic analysis. ACS Nano 5:7155-7167

45. Sisco PN, Wilson CG, Chernak D, Clark JC, Grzincic EM, Ako-Asare K, Goldsmith EC, Murphy CJ (2014) Adsorption of cellular proteins to polyelectrolyte-functionalized gold nanorods: a mechanism for nanoparticle regulation of cell phenotype? PLoS one 9. doi 10.1371/journal.pone.0086670

46. Albanese A, Walkey CD, Olsen JB, Guo H, Emili A, Chan W (2014) Secreted biomolecules alter the biological identity and cellular interactions of nanoparticles. ACS Nano 8:5515-5526

47. Patel PC, Giljohann DA, Daniel WL, Zheng D, Prigodich AE, Mirkin CA (2010) Scavenger receptors mediate cellular uptake of polyvalent oligonucleotide-functionalized gold nanoparticles. Bioconj Chem 21:2250-2256

48. Jiang X, Weise S, Hafner M, Rocker C, Zhang F, Parak WJ, Nienhaus GU (2010) Quantitative analysis of the protein corona on FePt nanoparticles formed by transferrin binding. J R Soc Lond Interface 7(Suppl 1):S5-S13

49. Treuel L, Brandholt S, Maffre P, Wiegele S, Shang L, Nienhaus GU (2014) Impact of protein modification on the protein corona on nanoparticles and nanoparticle-cell interactions. ACS Nano 8:503-513

50. Lesniak A, Fenaroli F, Monopoli MP, Aberg C, Dawson KA, Salvati A (2012) Effects of the presence or absence of a protein corona on silica nanoparticle uptake and impact on cells. ACS Nano 6:5845-5857

51. Lesniak A, Salvati A, Santos-Martinez MJ, Radomski MW, Dawson KA, Aberg C (2013) Nanoparticle adhesion to the cell membrane and its effect on nanoparticle uptake efficiency. J Am Chem Soc 135:1438-1444

52. Lunov O, Syrovets T, Loos C, Beil J, Delacher M, Tron K, Nienhaus GU, Musyanovych A, Mailander V, Landfester K, Simmet T (2011) Differential uptake of functionalized polystyrene nanoparticles by human macrophages and a monocytic cell line. ACS Nano 5:1657-1669

53. Peng Q, Zhang S, Yang Q, Zhang T, Wei XQ, Jiang L, Zhang CL, Chen QM, Zhang ZR, Lin YF (2013) Preformed albumin corona, a protective coating for nanoparticles based drug delivery system. Biomaterials 34:8521-8530

54. Lesniak A, Campbell A, Monopoli MP, Lynch I, Salvati A, Dawson KA (2010) Serum heat inactivation affects protein corona composition and nanoparticle uptake. Biomaterials 31:9511-9518

55. Yan Y, Gause KT, Kamphuis MM, Ang CS, O'Brien-Simpson NM, Lenzo JC, Reynolds EC, Nice EC, Caruso F (2013) Differential roles of the protein corona in the cellular uptake of nanoporous polymer particles by monocyte and macrophage cell lines. ACS Nano 7:10960-10970

56. Krais A, Wortmann L, Hermanns L, Feliu N, Vahter M, Stucky S, Mathur S, Fadeel B (2014) Targeted uptake of folic acid-functionalized iron oxide nanoparticles by ovarian cancer cells in the presence but not in the absence of serum. Nanomed Nanotechnol Biol Med, doi:10.1016/j.nano.2014.01.006

57. Prapainop K, Witter DP, Wentworth P (2012) A chemical approach for cell-specific targeting of nanomaterials: small-molecule-initiated misfolding of nanoparticle corona proteins. J Am Chem Soc 134:4100-4103

58. Caracciolo G, Cardarelli F, Pozzi D, Salomone F, Maccari G, Bardi G, Capriotti AL, Cavaliere C, Papi M, Lagana A (2013) Selective targeting capability acquired with a protein corona adsorbed on the surface of 1,2-dioleoyl-3trimethylammonium propane/DNA nanoparticles. ACS Appl Mater Interfaces 5:13171-13179

59. Ge C, Du J, Zhao L, Wang L, Liu Y, Li D, Yang Y, Zhou R, Zhao Y, Chai Z, Chen C (2011) Binding of blood proteins to carbon nanotubes reduces cytotoxicity. Proc Natl Acad Sci U S A 108:16968-16973

60. Hu W, Peng C, Lv M, Li X, Zhang Y, Chen N, Fan C, Huang Q (2011) Protein corona-mediated mitigation of cytotoxicity of graphene oxide. ACS Nano 5:3693-3700

61. Wang F, Yu L, Monopoli MP, Sandin P, Mahon E, Salvati A, Dawson KA (2013) The biomolecular corona is retained during nanoparticle uptake and protects the cells from the damage induced by cationic nanoparticles until degraded in the lysosomes. Nanomedicine 9:1159-1168

62. Wang L, Li J, Pan J, Jiang X, Ji Y, Li Y, Qu Y, Zhao Y, Wu X, Chen C (2013) Revealing the binding structure of the protein corona on gold nanorods using synchrotron radiation-based techniques: understanding the reduced damage in cell membranes. J Am Chem Soc 135:17359-17368

63. Doorley GW, Payne CK (2012) Nanoparticles act as protein carriers during cellular internalization. Chem Commun (Camb) 48:2961-2963

64. Speshock JL, Braydich-Stolle LK, Szymanski ER, Hussain SM (2011) Silver and gold nanoparticles alter cathepsin activity in vitro. Nanoscale Res Lett 6, doi 10.1007/S11671-010-9746-3

65. Vauthier C, Persson B, Lindner P, Cabane B (2011) Protein adsorption and complement activation for di-block copolymer nanoparticles. Biomaterials 32:1646-1656

66. Deng ZJ, Liang MT, Monteiro M, Toth I, Minchin RF (2011) Nanoparticle-induced unfolding of fibrinogen promotes Mac-1 receptor activation and inflammation. Nat Nanotech 6:39-44

67. Cifuentes-Rius A, de Puig H, Kah JCY, Borros S, Hamad-Schifferli K (2013) Optimizing the properties of the protein corona surrounding nanoparticles for tuning payload release. ACS Nano 7:10066-10074

68. Kah JCY, Chen J, Zubieta A, Hamad-Schifferli K (2012) Exploiting the protein corona around gold nanorods for loading and triggered release. ACS Nano 6:6730-6740

69. Faure AC, Dufort S, Josserand V, Perriat P, Coll JL, Roux S, Tillement O (2009) Control of the in vivo biodistribution of hybrid nanoparticles with different poly(ethylene glycol) coatings. Small 5:2565-2575

70. Lipka J, Semmler-Behnke M, Sperling RA, Wenk A, Takenaka S, Schleh C, Kissel T, Parak WJ, Kreyling WG (2010) Biodistribution of PEG-modified gold nanoparticles following intratracheal instillation and intravenous injection. Biomaterials 31:6574-6581

71. Niidome T, Yamagata M, Okamoto Y, Akiyama Y, Takahashi H, Kawano T, Katayama Y, Niidome Y (2006) PEGmodified gold nanorods with a stealth character for in vivo applications. J Controlled Release 114:343-347

72. Paciotti GF, Myer L, Weinreich D, Goia D, Pavel N, McLaughlin RE, Tamarkin L (2004) Colloidal gold: a novel nanoparticle vector for tumor directed drug delivery. Drug Deliv 11:169-183 
73. Ogawara K, Furumoto K, Nagayama S, Minato K, Higaki K, Kai T, Kimura T (2004) Pre-coating with serum albumin reduces receptor-mediated hepatic disposition of polystyrene nanosphere: implications for rational design of nanoparticles. J Controlled Release 100:451-455

74. Schaffler M, Sousa F, Wenk A, Sitia L, Hirn S, Schleh C, Haberl N, Violatto M, Canovi M, Andreozzi P, Salmona M, Bigini P, Kreyling WG, Krol S (2014) Blood protein coating of gold nanoparticles as potential tool for organ targeting. Biomaterials 35:3455-3466

75. Kratz F (2014) A clinical update of using albumin as a drug vehicle - a commentary. J Controlled Release, doi:10.1016/j.jconrel.2014.03.013

76. Mirshafiee V, Mahmoudi M, Lou K, Cheng J, Kraft ML (2013) Protein corona significantly reduces active targeting yield. Chem Commun (Camb) 49:2557-2559

77. Salvati A, Pitek AS, Monopoli MP, Prapainop K, Bombelli FB, Hristov DR, Kelly PM, Aberg C, Mahon E, Dawson KA (2013) Transferrin-functionalized nanoparticles lose their targeting capabilities when a biomolecule corona adsorbs on the surface. Nat Nanotech 8:137-143

78. Dai Q, Walkey C, Chan WCW (2014) Polyethylene glycol backfilling mitigates the negative impact of the protein corona on nanoparticle cell targeting. Angew Chem Int Edit 53:5093-5096

doi:10.1186/s12645-014-0007-5

Cite this article as: Brun and Sicard - Roselli: Could nanoparticle corona characterization help for biological consequence prediction? Cancer Nanotechnology 2014 5:7.

Submit your manuscript to a SpringerOpen ${ }^{\circ}$ journal and benefit from:

- Convenient online submission

- Rigorous peer review

- Immediate publication on acceptance

- Open access: articles freely available online

- High visibility within the field

- Retaining the copyright to your article

Submit your next manuscript at $\gg$ springeropen.com 